DOI: https://doi.org/10.32839/2304-5809/2020-12-88-42

удК 343.2

Седих Ю.О.

Дніпропетровський державний університет внутрішніх справ

\title{
КРИМІНАЛЬНА ВІДПОВІДАЛЬНІСТЬ ЗА ПРАВОПОРУШЕННЯ, ВЧИНЕНІ У СТАНІ АЛКОГОЛЬНОГО АБО НАРКОТИЧНОГО СП'ЯНІННЯ
}

\begin{abstract}
Анотація. У статті розглядаються питання кримінальної відповідальності за правопорушення, вчиненні у стані сп'яніння, яке виникає внаслідок вживання алкоголю, наркотичних засобів та інших одурманюючих речовин. Проведено аналіз кримінального законодавства в частині застосування такої обставини як обтяжуючої. Розглянуто різні точки зору щодо поняття стану сп'яніння і його значення для кваліфікації правопорушення і кримінальної відповідальності в цілому. Проаналізовано вітчизняне законодавство та наукові дослідження в частині кримінальної відповідальності за правопорушення, вчинені у стані сп'яніння, внаслідок вживання алкоголю, наркотичних засобів та інших одурманюючих речовин, на основі чого зроблено відповідні висновки, які мають як теоретичне, так і практичне значення щодо досліджуваного питання.
\end{abstract}

Ключові слова: правопорушення, кримінальна протиправність, пандемія, кримінальне законодавство, стан сп'яніння, осудність, пом'якшуючі обставини, обтяжуючі обставини.

Sedih Julia

Dnipropetrovsk State University of Internal Affairs

\section{CRIMINAL LIABILITY FOR OFFENCES COMMITTED UNDER THE INFLUENCE OF ALCOHOL OR DRUGS}

Summary. The article considers the issues of criminal liability for offences which were committed having been intoxicated. The article analyzes the criminal legislation in terms of applying such circumstances as the aggravating factor. This paper presents diverse views on the concept of intoxication and its meaning for the classification of an offence and criminal liability in general. The national legislation and scientific researches related to criminal liability for offences committed intoxicated due to the use of alcohol, narcotic drugs and other intoxicating substances have been analysed based on which the relevant conclusions which have both theoretical and practical significance for the matter have been made. The article provides a thorough and detailed analysis of statistical data of the General Prosecutor's Office for ten months of 2020 on registered criminal offenses and the results of preliminary investigation of criminal offenses committed by persons under the influence of alcohol. The increased public danger of committing offenses in a state of intoxication, which occurs as a result of alcohol, drugs and other intoxicating substances, various measures used by the state to combat this social phenomenon are substantiated. Currently, there is no single comprehensive point of view of experts on the problem of differentiation of criminal responsibility of persons who have committed offences while intoxicated. Criminal legislation remains subject to change. Prevention of offenses in a state of intoxication is one of the priority tasks of the state. In the implementation of this task an important role is played by the norms of criminal law, providing responsibility for offenses committed while intoxicated, provides the importance of theoretical research emerging in this area and issues of improvement of the legislative material and practice of its application. Thus, the study is designed on the basis of previously issued and recently available theoretical research materials on the basis of current editions of normative acts to clarify and deepen the provisions of previously conducted research to fill existing gaps.

Keywords: offence, criminal illegality, pandemic, criminal legislation, intoxication, sanity, mitigating circumstances, aggravating circumstances.

Постановка проблеми. Правовий прогрес, до якого прагне Україна, здійснюючи запровадження в життя ідеї громадянського суспільства та демократичної, соціальної, правової держави, розбудова України як правової незалежної держави, що орієнтуеться у своїй діяльності на високі світові стандарти, забезпечення якості життя своїх громадян, - неможливі без якнайшвидшого подолання нею низки негативних явищ, що загрожують головним соціальним цінностям. Одніею із таких загроз генофонду нації й національній безпеці України стало стрімке поширення в країні немедичного вживання психоактивних речовин, наркотизація населення тощо.

Аналіз останніх досліджень і публікацій. Питання кримінальної відповідальності за правопорушення, вчинені у стані сп'яніння, внаслідок вживання алкоголю, наркотичних засобів та інших одурманюючих речовин розгля- далися у працях таких вчених, як Ю.М. Антонян, В.В. Беспалько, О.В. Бугрім, В.М. Бурдін, О.О. Кашкаров, В.И. Кононенко, В.Г. Кундеус, В.T. Маляренко, А.М. Нагорна, О.С. Стеблинська, О.Б. Шигонін та ін.

Виділення не вирішених раніше частин загальної проблеми. Положення чинного закону про кримінальну відповідальність вказують на те, що особа підлягае кримінальній відповідальності за кримінальне правопорушення, вчинене у стані алкогольного чи наркотичного сп'яніння. Дослідження впливу стану сп'яніння на кримінальну відповідальність обумовлене, в першу чергу, потребою сучасного суспільства в правовому захисті громадян від кримінально протиправних посягань, скоєних особами, які перебувають у стані сп'яніння. Незважаючи на грунтовність та значущість проведених наукових досліджень, питання кримінально-правової 
регламентації правопорушень, вчинених у стані сп'яніння залишаються актуальними і потребують значної уваги в окресленому напрямі.

Мета статті. Головною метою цієї роботи є дослідження особливостей правового регулювання правопорушень, вчинених у стані сп'яніння, внаслідок вживання алкоголю, наркотичних засобів та інших одурманюючих речовин.

Виклад основного матеріалу. Незаконний обіг наркотичних засобів, психотропних речових та їх аналогів, контрабанда наркотичних засобів, поширення наркоманії належать до чинників, які загрожують глобальній міжнародній стабільності та негативно позначаються на безпековому середовищі України [1, с. 140]. Отже, в сучасних умовах важливого значення набувають питання алкоголізму та наркоманії, зокрема питання кримінальної відповідальності за правопорушення, вчинені у стані сп'яніння, внаслідок вживання алкоголю, наркотичних засобів та інших одурманюючих речовин.

Протягом останніх років в Україні зберігається складна криміногенна обстановка, не вдалося призупинити процес криміналізації суспільства, злочинність прагне поширити свій вплив і на ті суспільні та економічні інститути, які ще до недавнього часу вважалися надійно захищеними від неї. Серед негативних явищ, властивих сучасній цивілізації, алкоголізм займає особливе місце, обумовлене масштабністю і різноманітністю можливої і фрактично завданої соціуму шкоди. Особливо це стосується ситуації під час пандемї вірусу COVID-2019. Чимало правозахисників, як однією з особливих проблем карантину вважають зловживання алкоголем.

Алкогольний колапс. Сплеск домашнього насильства, безпосередньо пов'язаний з пияцтвом. Алкоголь - це, безумовно, фрактор, що підсилюе проблему. Наприклад, у стані сп'яніння чоловікагресор може втратити контроль, зайти далі, схопитися за ніж.

Коли йде мова про особу, яка вчиняе домашне насильство, то скоріш за все, це люди які не можуть тримати себе в руках. Вони більш дратівливі, знімають напругу за рахунок виходу агресії. Момент психологічно складний для багатьох - вони зазнають збитків, втрачають роботу, відмовляються від планів на відпочинок. Агресивність у людей, схильних до насильства, в такі часи прогресує.

Алкоголізм впливає буквально на всі сфери життя суспільства: фрізичне і духовне здоров'я нації, її культуру, суспільне виробництво і економіку в цілому, обороноздатність, процес відтворення населення і т.д. Особлива система взаємин складаеться між алкоголізмом і злочинністю. Алкоголізм надає істотний вплив на їі стан, структуру і динаміку.

Щорічно близько 56 \% вбивств (або замаху на вбивство), 60 \% випадків заподіяння шкоди здоров'ю різного ступеня тяжкості, $87 \%$ хуліганства, 60 \% автотранспортних правопорушень в Україні відбуваються у стані сп'яніння. Негативна динаміка цих правопорушень обумовлюе необхідність їх ефрективного попередження, успіх якого багато в чому залежить від правильної оцінки в генезисі кримінально протиправної поведінки.
Аналіз статистичних даних Генеральної прокуратури за десять місящів 2020 року щодо зареєстрованих кримінальних правопорушень та результатів їх досудового розслідування вказуе на те, що усього кримінальних правопорушень, вчинених особами у стані алкогольного сп'яніння є 7 970, з них особливо тяжких злочинів - 431, тяжких злочинів - 1945 , нетяжких злочинів - 812, кримінальних проступків - 1252. Із загальної кількості кримінальних правопорушень, вчинених за досліджуваний період, злочинами проти основ національної безпеки України $\epsilon-0$, кримінальними правопорушеннями проти життя та здоров'я особи - 3 420, кримінальними правопорушеннями проти волі, честі та гідності особи - 17, кримінальними правопорушеннями проти статевої свободи та статевої недоторканності особи - 86, кримінальними правопорушеннями проти виборчих, трудових та інших особистих прав і свобод людини і громадянина - 236, кримінальними правопорушеннями проти власності - 2 461, кримінальними правопорушеннями у сорері господарської діяльності - 0, кримінальними правопорушеннями проти довкілля - 0 , кримінальними правопорушеннями проти громадської безпеки - 120, кримінальними правопорушеннями проти безпеки виробництва - 0 , кримінальними правопорушеннями проти безпеки руху та експлуатації транспорту - 653, кримінальними правопорушеннями проти громадського порядку та моральності - 352, кримінальними правопорушеннями у сфрері обігу наркотичних засобів, психотропних речовин, їх аналогів або прекурсорів та інші кримінальні правопорушення проти здоров'я населення - 51, кримінальними правопорушеннями у сфері охорони державної таємниці, недоторканності державних кордонів, забезпечення призову та мобілізації - 0, кримінальними правопорушеннями проти авторитету органів державної влади, органів місцевого самоврядування, об'єднань громадян та кримінальні правопорушення проти журналістів - 359, кримінальними правопорушеннями у сфрері використання електронно-обчислювальних машин (комп'ютерів), систем та комп'ютерних мереж і мереж електрозв'язку - 0, кримінальними правопорушеннями у сфрері службової діяльності та профресійної діяльності, пов'язаної з наданням публічних послуг - 170, кримінальними правопорушеннями проти правосуддя - 33, кримінальними правопорушеннями проти встановленого порядку несення військової служби (військові кримінальні правопорушення) - 11, кримінальними правопорушеннями проти миру, безпеки людства та міжнародного правопорядку - 1 [2].

Згідно зі ст. 49 Конституції України, кожна людина має право на охорону здоров'я, і держава повинна забезпечити їй це право. Забезпечення кримінально-правового захисту здоров'я людей здійснюеться в межах, передбачених статтями 305-327 розділу XIII «Кримінальні правопорушення у сфрері обігу наркотичних засобів, психотропних речовин, їх аналогів або прекурсорів та інші кримінальні правопорушення проти здоров'я населення» Особливої частини Кримінального кодексу України [3].

Поширення наркоманії та наркозлочинності в Україні на сьогодні стало однією 3 найгостріших 
суспільних проблем [4, с. 40], нерозв’язання якої призводить до заподіяння шкоди здоров'ю людини, негативного впливу на соціальну сфреру, а також є загрозою національній безпеці держави в цілому. Значне місце в протидії незаконному обігу наркотичних засобів, психотропних речовин і прекурсорів займає кримінальна відповідальність як один 3 кримінально-правових заходів, за допомогою якого обмежуеться можливість вчинення кримінальних правопорушень у сфрері обігу наркотичних засобів і психотропних речовин. Правопорушення проти здоров'я населення - це передбачені розділом XIII Особливої частини КК суспільно-небезпечні умисні або необережні діяння, які створюють загрозу заподіяння шкоди або заподіюють фрактичну шкоду здоров'ю невизначеного кола осіб від незаконного обігу наркотичних засобів, психотропних речовин, їх аналогів і прекурсорів, від дії отруйних, сильнодіючих речовин і одурманюючих засобів, біологічних агентів і токсинів, від впливу радіоактивно забрудненої продукщії, а також від поширення епідемій.

Розділ XIII КК України містить суспільно-небезпечні діяння, які за особливостями об'єкту посягання, характером і змістом об'єктивної сторони можна віднести до двох категорій: по-перше, це правопорушення у сорері обігу наркотичних засобів психотропних речовин, їх аналогів або прекурсорів; по-друге, - інші правопорушення проти здоров'я населення.

В цих умовах особливої актуальності набуває всебічне і глибоке дослідження всіх тісно взаємопов'язаних між собою аспектів алкоголізму, як складного негативного соціального dpeномену. Тільки на основі такого вивчення може бути розроблений дієвий механізм впливу на дане соціальне явище.

Положення про відповідальність за вчинення подібних правопорушень у вітчизняному кримінальному законодавстві знайшло відображення не одразу. За своєю суттю кримінальну відповідальність довгий час було передбачено лише за вчинення кримінально протиправного діяння в стані алкогольного сп'яніння, яке на розсуд суду могло бути визнано обтяжуючою обставиною. Водночас, згідно зі ст. 21 Кримінального кодексу України 2001 р., відповідальність настає за вчинення правопорушення у стані алкогольного, наркотичного чи іншого сп'яніння або під впливом лікарських препаратів, що знижують увагу та швидкість реакції.

Найчастіше суспільно небезпечні діяння вчиняють у стані алкогольного сп'яніння. Вирішуючи питання про кримінальну відповідальність за правопорушення, які мають алкогольне підгрунтя, необхідно знати про вплив алкоголю на загальний стан та психіку особи. Алкоголь, діючи на організм людини, вражає їі свідомість та волю тим сильніше, чим важчий ступінь сп'яніння. Основний вплив алкоголю - сп'яніння. Натомість, безпосередній вплив алкоголю та дія алкоголю на організм людини визначаеться не тільки кількістю вжитого спиртного, а й його міцністю. Умовно просте алкогольне сп'яніння поділяють на такі стадії: легке, середне та тяжке сп'яніння. Варто звернути увагу й на те, що через відсутність у діях особи, яка перебуває у стані сп'яніння, критерї̈в неосудності вона в будь- якому разі є суб'єктом правопорушення i не звільняеться від кримінальної відповідальності.

Також 3 кожним днем все більш актуальними стають питання боротьби не тільки з таким негативним соціальним явищем, як алкоголізм, але також і з незаконним обігом нових потенщійно небезпечних психоактивних речовин [5, с. 95-97].

Стан простого алкогольного, наркотичного або токсичного сп'яніння не визначається психічним розладом, недоумством або іншим хворобливим станом психіки, в чому солідарні більшість юристів і психіатрів, які разом 3 тим відзначають, що стан сп'яніння, в залежності від ступеня сп'яніння, впливає на нормальний перебіг психічних процесів, дезорганізуе процес збудження і гальмування, а також впливає на здатність адекватно реагувати на події.

Поведінка особи в стані сп'яніння залежить не тільки від дози спожитих психоактивних речовин, але і від виховання, культурного рівня, звичок, фізіологічних особливостей організму тощо, це $€$ ще однією з причин, що не дозволяють віднести стан сп'яніння до хворобливих станів психіки.

Що стосується юридичного (психологічного) критерію неосудності або обмеженої осудності, то в більшості випадків особа, яка вчиняє правопорушення в стані сп'яніння, зберігає здатність керувати своїми діями (бездіяльністю).

Поведінка людини, що знаходиться в стані сп'яніння, часто нелогічна, на перший погляд безмотивна, часто цинічна і жорстока, що дозволяє поставити під сумнів психічне здоров'я суб'єкта і його здатність керувати своєю поведінкою. І тільки комплексна психолого-психіатрична експертиза, частіше стаціонарна, здатна зробити висновок про наявність чи відсутність медичного і юридичного критеріїв неосудності або обмеженої осудності [6, с. 14].

Юридичний критерій неосудності поділяється на інтелектуальний, що являє собою нездатність особи усвідомлювати фрактичний характер і суспільну небезпеку своїх дій (бездіяльності), і вольовий, що виражається в нездатності особи керувати своїми діями (бездіяльністю). Прикладом вольового критерію може бути стан абстиненщії (наркотичного голодування), в разі якщо людина, що страждає наркоманією, не в змозі подолати процес ломки, здатна незаконно заволодіти медичними препаратами, що містять наркотичні речовини, в аптеці. При цьому винний повною мірою усвідомлюе фрактичний характер і суспільну небезпеку своїх дій і передбачає настання відповідних наслідків і покарання. Для наявності юридичного критерію у формулі неосудності досить одніеї із зазначених ознак.

До медичного критерію неосудності відносять хронічний психічний розлад, тимчасовий психічний розлад, слабоумство або інший хворобливий стан психіки.

Звичайне сп'яніння, навіть в тому випадку, якщо воно тягне за собою втрату особою здатності усвідомлювати свої дії або керувати ними, не може розглядатися в межах неосудності, оскільки в цьому випадку відсутній медичний критерій, тобто наявність у особи психічного розладу, який паралізуе або істотно обмежуе можливості його свідомості і волі.

Разом $з$ тим, встановлюючи можливість визнання вчинення правопорушення в стані сп'яніння 
обтяжуючою обставиною i пропонуючи робити це 3 урахуванням характеру і ступеня тяжкості вчиненого правопорушення, обставин вчинення правопорушення (які, взагалі-то, і визначають ступінь тяжкості вчиненого правопорушення і вже знайшли свое відображення в переліку обтяжуючих покарання обставин) і особи винного, законодавець фрактично пропонує звертатися до критеріїв індивідуалізації покарання.

Перелік обставин, що обтяжують покарання, $є$ вичерпним. Так, включення якої-небудь обставини в перелік обтяжуючих чи пом'якшуючих покарання має відповідати певним вимогам: нехарактерні обставини для більшості кримінально протиправних діянь і значущість впливу на покарання. Аналізуючи критерії включення конкретної обставини в законодавчі переліки, слід звернути увагу на типовість обставин (можливість їх існування в більш-менш широкому колі правопорушень), обов'язковість впливу (безумовність впливу) на міру покарання у всіх випадках, коли воно в наявності, незалежно від конкретних особливостей кримінально протиправного діяння і особи винного, і визначення певної спрямованості впливу (вказана в переліку обставина здатна при здійсненні будь-яких правопорушень або підвищувати, або тільки знижувати суспільну небезпеку і покарання) [7, с. 140].

Тільки сукупність зазначених ознак дає підстави законодавчого визнання конкретної обставини такою, що обтяжує покарання.

Відповідно до п. 13 ст. 67 КК України, при призначенні покарання, вчинення кримінального правопорушення особою, що перебуває у стані алкогольного сп'яніння або у стані, викликаному вживанням наркотичних або інших одурманюючих засобів визнається обставиною, яка його обтяжує. Залежно від характеру вчиненого кримінального правопорушення суд має право не визнати цю обставину такою, що обтяжуе покарання, навівши мотиви свого рішення у вироку.

Можливі також ситуації, коли знаходження особи в момент вчинення правопорушення в стані сп'яніння може бути віднесено до обставин, що пом'якшують покарання або до нейтральної обставини (наприклад, вчинення правопорушення хоча і в стані сп'яніння, але цей стан виник в результаті обманного введення психоактивних речовини в організм людини). Отже, у всіх випадках вирішення питання про вплив стану сп'яніння на міру покарання відбувається на розсуд суду [8, с. 75].

Висновки та пропозиції. Отже, необхідно зазначити, що вчинення кримінального правопорушення в стані сп'яніння, безумовно, повинно впливати на ступінь провини і міру відповідальності правопорушника. Високий ступінь суспільної небезпеки правопорушень, вчинених у стані сп'яніння, тяжкість їх наслідків, а також досвід правозастосовної практики свідчать про потребу протидії такого роду явищ. Тому, вважаємо за доцільне, на підставі того, що більшість правопорушень вчиняеться саме у стані сп'яніння (як показує практика, саме алкогольного) необхідно розширити перелік складів кримінальних правопорушень, в яких би стан сп'яніння був однією 3 кваліфрікуючих ознак. Така точка зору вже висловлювалася в наукових дослідженнях [6, с. 13]. До цього переліку необхідно віднести статті, що забезпечують кримінально-правовий захист права на життя і здоров'я особи (ст. 115-145 КК України); статеву недоторканість і статеву свободу особи (ст. 152-156 КК України); власність (ст. 185-198 КК України); громадський порядок і моральність (ст. 293-304 КК України).

Статистичні дані Генеральної прокуратури за десять місяців 2020 року вказують на доволі велику кількість зареєстрованих кримінальних правопорушень, вчинених особами у стані алкогольного сп'яніння.

В інтересах захисту суспільних відносин, необхідно постійно вдосконалювати кримінально-правові заходи боротьби зі злочинністю осіб, які перебувають у стані сп'яніння. Зокрема, це пов'язано із відповідністю нормативно-правового регулювання умовам соціальної дійсності, забезпеченням редормування правової системи за умов внутрішньої та зовнішньої матеріальнотехнічної підтримки тощо.

\section{Список літератури:}

1. Горпинюк О.П. Сучасний стан наркозлочинності в Україні. Актуальні проблеми вітчизняної юриспрудениї̈. 2017. № 4. С. 140-143.

2. Статистична інформація про зареєстровані кримінальні правопорушення та результати їх досудового розслідування за жовтень 2020 p. URL: https://old.gp.gov.ua/ua/stst2011.html?dir_id=114141\&libid=100820\&c= (дата звернення: 03.11.2020).

3. Кримінальний кодекс України : Закон України від 05.04.2001 p. № 2341-III. URL: https://zakon.rada.gov.ua/ laws/card/2341-14 (дата звернення: 10.11.2020).

4. Воронін В.М. Обтяжуючі обставини, що впливають на ступінь суспільної небезпеки злочину, і їх відображення в сучасній судовій практиці. Адвокат. 2016. № 1. С. 35-46.

5. Бабанов А.С. Кримінальна відповідальність за злочини, вчинені в стані сп'яніння : дис. : 12.00.08. Донецьк, 2012. $219 \mathrm{c}$.

6. Кисельов М.В. Правові наслідки стану сп'яніння засуджених до позбавлення волі. Вісник інституту: злочин, покарання, виправлення. Вологда, 2014. № 1(25). С. 13-16.

7. Науково-практичний коментар Кримінального кодексу України / Д.С. Азаров, В.К. Грищук, А.В. Савченко та ін. ; за заг. ред. О.М. Джужі, А.В. Савченка, В.В. Чернея. Київ, 2016. 1064 с.

8. Колесник В.А. Судова психіатрія : курс лекцій. Київ : Юрінком Інтер, 2000. 128 с.

\section{References:}

1. Horpyniuk O.P. (2017) Suchasnyi stan narkozlochynnosti v Ukraini [The current state of drug crime in Ukraine]. Aktualni problemy vitchyznianoi yurysprudentsii, no. 4, pp. 140-143.

2. Statystychna informatsiia pro zareiestrovani kryminalni pravoporushennia ta rezultaty yikh dosudovoho rozsliduvannia za zhovten 2020 r. (2020) [Statistical information on registered criminal offenses and the results of their pre-trial investigation for October 2020]. Kyiv: Heneralna prokuratura Ukrainy. 
3. Kryminal'nyj kodeks Ukrai'ny: Zakon Ukrai'ny vid 05 kvitnja 2001 roku [The Criminal Code of Ukraine: Law of Ukraine of April 05, 2001]. Available at: https://zakon.rada.gov.ua/laws/show/4025-17 (accessed 10.01.2020).

4. Voronin V.M. (2016) Obtiazhuiuchi obstavyny, shcho vplyvaiut na stupin suspilnoi nebezpeky zlochynu, i yikh vidobrazhennia v suchasnii sudovii praktytsi [Aggravating circumstances affecting the degree of public danger of the crime and their reflection in modern judicial practice]. Advokat, no. 1, pp. 35-46.

5. Babanov A.S. (2012) Kryminalna vidpovidalnist za zlochyny, vchyneni v stani spianinnia [Criminal liability for crimes committed while intoxicated]. Donetsk, $219 \mathrm{p}$.

6. Kyselov M.V. (2014) Pravovi naslidky stanu spianinnia zasudzhenykh do pozbavlennia voli [Legal consequences of the state of intoxication of convicts]. Visnyk instytutu: zlochyn, pokarannia, vypravlennia, no. 1(25), pp. 13-16.

7. Naukovo-praktychnyi komentar Kryminalnoho kodeksu Ukrainy (2016) [Scientific and practical commentary on the Criminal Code of Ukraine]. Kyiv, $1064 \mathrm{p}$.

8. Kolesnyk V.A. (2000) Sudova psykhiatriia: kurs lektsii [Forensic psychiatry: a course of lectures]. Kyiv, 128 p. 